\title{
CH50 Measurement
}

National Cancer Institute

\section{Source}

National Cancer Institute. CH50 Measurement. NCI Thesaurus. Code C100423.

A measurement of the complement required to lyse 50 percent of red blood cells in a biological specimen. 